\title{
Brief review of the mRNA vaccines COVID-19
}

\author{
Antonio Vitiello ${ }^{2}\left[\right.$. Francesco Ferrara ${ }^{1}[0$
}

Received: 18 March 2021 / Accepted: 16 April 2021 / Published online: 1 May 2021

(c) The Author(s), under exclusive licence to Springer Nature Switzerland AG 2021

\begin{abstract}
The global COVID-19 pandemic continues to claim victims worldwide, representing a health and socioeconomic challenge with few precedents in human history. The therapeutic agents used to treat COVID-19 infection are mostly aimed at avoiding the most serious complications and organ damage that in a percentage of cases can be fatal. Recently, the first COVID-19 vaccines have been authorised, starting a massive vaccination campaign worldwide. The COVID-19 vaccines authorized or under testing use different methods of action such as mRNA, DNA vaccine, viral vector, protein subunit, and virus inactivated immunization strategies. The mRNA vaccines are the first authorised vaccines with this new method of action, initiating a new era of preventive medicine. To date, data indicate that they may be effective against the newly identified SARS-CoV-2 variants. Short-term studies indicated an acceptable safety profile but long-term immunity as well as safety is not yet available. In this article, we briefly describe mRNA vaccines and highlight some aspects yet to be fully defined.
\end{abstract}

Keywords Covid-19 $\cdot$ mRNA $\cdot$ Pharmacology $\cdot$ Vaccine

\section{Introduction}

In November 2019, a new RNA Coronavirus (SARS-CoV-2) responsible for a severe acute respiratory syndrome was identified in China; the disease was defined as COVID-19 (Coronavirus disease 2019) (Zhu et al. 2019; Wang et al. 2020a). The rapid and exponential increase in the number of cases suggested the possibility of human-to-human transmission (Huang et al. 2020) (Li et al. 2020) (Zhu et al. 2019) (Gorbalenya 2020). The World Health Organization (WHO) declared this new viral disease a global public health emergency on January 30, 2020, and subsequently declared global pandemic status SARS-CoV-2 (COVID-19) on March 11, 2020 (Guarner 2020). To date, data record approximately 106 million infected individuals and 2.32 million deaths due to COVID-19, worldwide (https://www.who.int/

Francesco Ferrara

francesco.ferrara@uslumbria1.it

Antonio Vitiello

antonio.vitiello2@uslumbria1.it

1 Hospital Pharmacist Manager, Pharmaceutical Department, Usl Umbria 1, A.Migliorati Street, 06132 Perugia, Italy

2 Clinical Pharmacologist, Pharmaceutical Department, Usl Umbria 1, A.Migliorati Street, 06132 Perugia, Italy emergencies/diseases/novelcoronavirus2019/situation-repor ts) (WHO 2021).

\section{COVID-19, clinical symptoms and treatments}

The main mode of transmission COVID-19 is human-tohuman through inhalation of droplets generated by coughing and sneezing of positive patients (Harrison et al.2020). SARS-CoV-2 infection in most cases has an asymptomatic or mildly symptomatic course (Oran et al. 2020). The most common symptoms are elevation of body temperature, fatigue, coughing loss of sense of smell (Hoang et al.2020). In a percentage of patients, especially elderly individuals with pre-existing conditions, COVID-19 infection can cause severe organ damage that in some cases is fatal (Vitiello et al. 2020a, b; Ferrara 2020). Since the onset of the COVID19 pandemic, numerous pharmacological treatments have been tested to treat the viral infection, mostly directed at avoiding the most severe complications (Vitiello and Ferrara 2020a; Wang et al. 2020b). There is a scarcity of proven clinical data related to therapeutic agents to combat COVID19 and the urgency to act quickly have suggested the use of pharmacological agents already on the market used for other therapeutic indications which include anti-inflammatory, antiviral, and anticoagulants. The antivirals Remdesivir and Lopinavir/Ritonavir (Vitiello and Ferrara 2020b; Al-Tawfiq 
et al. 2020; Ferrara et al. 2020a) have shown anti-COVID-19 efficacy in some studies (Chu et al. 2004; Vitiello and Ferrara 2021; Cao et al. 2020). Several immunomodulators have been used to reduce the generalized hyperinflammatory state caused by cytokine storm, such as Tocilizumab, colchicine, eculizumab, dexamethasone (Somers et al. 2020; Campochiaro et al. 2020; Reyes et al. 2020; Deftereos et al. 2020). Other experimental pharmacological approaches are directed at limiting cardiac, pulmonary, and hepatic damage(Wijnsma et al. 2019; Horby 2020; Ferrara et al. 2020b). Authorised monoclonal antibodies such as Casirivimab, Imdevimab, Bamlanivimab inhibit viral entry into host cells and are used in SARS-CoV-2 positive patients with a high risk of being hospitalized and having severe complications (Vitiello and Ferrara 2020b, 2021; Ferrara and Vitiello 2021). The COVID-19 patient, particularly with pre-existing comorbidities, is a complex patient; the safety of the therapeutic treatments used must also be carefully monitored (Vitiello et al. 2021a). Recently, the first COVID-19 vaccines have been authorised, representing the most powerful weapon available to stop the pandemic.

\section{Vaccines mRNA against COVID-19}

The authorised or under testing COVID-19 vaccines use different methods, messenger RNA (mRNA), viral vector, DNA vaccine, protein subunit, and virus inactivated immunizations (EMA 2021). The mRNA vaccines against COVID-19 are the first mRNA vaccines to be authorised, representing the beginning of a new era for preventive medicine (Dai et al. 2021). The mRNA vaccines have several advantages over traditional and conventional vaccines, such as the ability to develop and manufacture quickly and at low cost, efficacy and to date acceptabler safety profile (Locht et al. 2020; Wang et al. 2020c). This rapid production methodology has allowed for COVID-19 vaccines in a very short time. In COVID-19 mRNA vaccines, the mRNA molecule is encapsulated in lipid nanoparticles, which facilitate mRNA uptake and endocellular penetration which appear to protect against degradation (Zhang et al. 2020). The vaccine mRNA is delivered at the level of the muscle deltoid, the encapsulated mRNA enters the muscle cells, transits into the cytosol, and the ribosomes perform cellular translation producing the spike protein (S), which when released into the circulation stimulates the immune response. The spike protein (S) is critical for endocellular entry of SARSCoV-2 (Vitiello et al. 2021b, c, d), It is also responsible for the induction of neutralizing antibodies. Some studies have demonstrated antibody and cell-mediated immune responses induced by mRNA vaccines (Laczkó et al. 2020; Lederer et al. 2020). However, the duration of persistence of the antibody response against SARS-CoV-2 remains to be elucidated and to be identified by clinical studies; it is probably dependent on the individual host response. Recent evidence, however, shows that the antibody response is not the only one produced by mRNA vaccines and argues that another important weapon to defend against Sars-Cov-2 is cellular immunity through the development of specific $\mathrm{T}$ lymphocytes (Sewell et al. 2020). A most critical question is, how long does cell-mediated immunity protect people from a new COVID-19 infection? Furthermore, does the action of $\mathrm{T}$ lymphocytes prevent transmission of the virus to other individuals? Certainly, the decrease in the number of people with severe COVID-19 infection, mediated by vaccination, will also decrease the duration time of transmission and contagiousness, indirectly reducing also the contagion between men. In addition, evidence shows also a reduction in the number of asymptomatic cases in vaccinated individuals (Tande et al. 2021). Moreover, new variants of SARSCoV-2 have recently been identified in the United Kingdom and South Africa (Conti et al. 2021; Giovanetti et al. 2021). These new variants share the N501Y substitution, which affects the spike (S) protein and the viral receptor binding site for cell entry. Early epidemiological evidence shows that mRNA vaccine-induced immune responses may be effective in neutralizing these novel variants (Bleier et al. 2021; Holm et al. 2021).

\section{Safety aspects}

Every therapeutic, curative, prophylactic and preventive drug treatment, such as vaccines, is always subject to strict monitoring of the safety profile and of the benefit/risk ratio since the pre-registration studies. This is even more so for vaccines that are administered to healthy subjects. The mRNA vaccine development and manufacturing process does not require toxic chemicals or cell culture, and the short production time presents a very low risk of contamination of microorganisms (Wang et al. 2020c). The mRNA vaccines to date are considered a safe vaccine method. A clinical trial shows that the most commonly reported systemic events after administration of COVID-19 mRNA vaccine were fatigue and headache, although fatigue and headache were also reported in patients taking placebo (Polack et al. 2020). Serious systemic events were reported in less than $2 \%$ of vaccine recipients. Fever (temperature $\geq 38^{\circ} \mathrm{C}$ ) was reported after the second dose by $16 \%$ of vaccine recipients (Polack et al. 2020). Systemic events including fever and chills were observed within the first 1-2 days after vaccination and resolved shortly thereafter (Polack et al. 2020). No deaths were considered by the investigators to be related to the vaccine or placebo (Polack et al. 2020).

Anaphylaxis to COVID-19 mRNA vaccines is currently estimated at 2.5-11.1 cases per million doses, largely in individuals with a history of allergy (Shimabukuro et al. 2021). A large study investigated the incidence of an acute 
allergic reaction after more than 60.000 administrations of the COVID-19 mRNA vaccine. Acute allergic reactions were detected in 1365 employees (2.10\%). Anaphylaxis was confirmed in 16 employees $(0.025 \%)$ The meantime to the onset of anaplylasxis was $17 \mathrm{~min}$ (Blumenthal et al. 2021). The viral vector vaccine (Astrazeneca) may be associated with very cases of blood clots associated with trombocytopenia, i.e., low levels of blood platelets with or without bleeding, including rare cases of clots in the vessels draining blood from the brain (CVST) (https://www.ema.europa.eu/ en/news/covid-19-vaccine-astrazeneca-benefits-still-outwe igh-risks-despite-possible-link-rare-blood-clots) To date there are no similar cases with mRNA vaccines.

\section{Discussions}

Vaccines represent the most powerful weapon available to slow the growing pandemic of elucidated COVID-19. While early clinical data show efficacy even against new emerging variants and safety data of mRNA vaccines against COVID-19 are reassuring, some aspects need to be clarified. Two mRNA vaccines (Pfizer and Moderna) involve two administrations a few weeks apart. The Johnson and Johnson mRNA vaccine has a single administration. It can be assumed that the duration of clinically significant antibody response induced by mRNA vaccines will need to be closely monitored in postmarketing clinical trials. In addition, for individuals who have been infected and have recovered with measurable antibodies, at what point in time would it be advisable to vaccinate? For vaccines that involve double dose administration, is it indicated to administer only one dose? In addition, should certain categories of patients, such as cancer or organ transplant patients and those on immunosuppressive therapy, receive the same doses at the same interval as healthy individuals, or can the interval between doses be shortened? To date, these questions have not been answered. And finally, how long will immunity last? Will widespread immunity limit the spread of the virus in the population? To the latter answer, early data suggest that there is a reduction in the number of infected. Preventive vaccination is the safest and cheapest way to stop the COVID-19 pandemic, and mRNA vaccines represent the beginning of a new era of preventive medicine. To date, clinical data show very good efficacy and acceptable safety for mRNA vaccines against COVID-19. However, further clinical data are urgently needed to clarify these important questions.

\section{Conclusions}

This brief review, and these presented data indicate that mRNA vaccines are safe and effective, and represent a very viable weapon to stop the global COVID-19 pandemic. RNA-based vaccines are a promising new approach to protect humans not only from SARS-CoV-2 but from infectious diseases, with the advantage of rapid production and sufficient resource investment.

Author contributions AV: Conceptualization, Writing —original draft, Methodology, Writing — original draft. FF: Writing — review and editing, Supervision, Validation. All authors read and approved the manuscript and all data were generated in-house and that no paper mill was used.

Funding None.

Availability of data and materials Full availability of data and materials.

\section{Declarations}

Conflict of interest None of the Authors have conflicts of interest to disclose.

Consent to Publish The authors consent to the publication of the manuscript.

\section{References}

Al-Tawfiq JA, Al-Homoud AH, Memish ZA (2020) Remdesivir as a possible therapeutic option for the COVID-19. Travel Med Infect Dis. 34:101615. https://doi.org/10.1016/j.tmaid.2020.101615

Bleier BS, Ramanathan M Jr, Lane AP (2021) COVID-19 vaccines may not prevent nasal SARS-cov-2 infection and asymptomatic transmission. Otolaryngol Head Neck Surg 164(2):305-307. https://doi.org/10.1177/0194599820982633

Blumenthal KG, Robinson LB, Camargo CA Jr et al (2021) Acute allergic reactions to mrna COVID-19 vaccines. JAMA. https:// doi.org/10.1001/jama.2021.3976

Campochiaro C, Della-Torre E, Cavalli G et al (2020) Efficacy and safety of tocilizumab in severe COVID-19 patients: a singlecentre retrospective cohort study. Eur J Intern Med 76:43-49. https://doi.org/10.1016/j.ejim.2020.05.021

Cao B, Wang Y, Wen D et al (2020) A trial of lopinavir-ritonavir in adults hospitalized with severe Covid-19. N Engl J Med 382(19):1787-1799. https://doi.org/10.1056/nejmoa2001282

Chu CM, Cheng VC, Hung IF et al (2004) Role of lopinavir/ritonavir in the treatment of SARS: initial virological and clinical findings. Thorax 59(3):252-256. https://doi.org/10.1136/thorax. 2003.012658

Conti P, Caraffa A, Gallenga CE et al (2021) The British variant of the new coronavirus-19 (Sars-Cov-2) should not create a vaccine problem. J Biol Regul Homeost Agents 35(1):1-4. https:// doi.org/10.23812/21-3-E (PMID: 33377359) 
Dai L, Gao GF (2021) Viral targets for vaccines against COVID19. Nat Rev Immunol 21(2):73-82. https://doi.org/10.1038/ s41577-020-00480-0

Deftereos SG, Giannopoulos G, Vrachatis DA (2020) Effect of colchicine vs standard care on cardiac and inflammatory biomarkers and clinical outcomes in patients hospitalized with coronavirus disease 2019: the GRECCO-19 randomized clinical trial. JAMA Netw Open 3(6):e2013136. https://doi.org/10.1001/ jamanetworkopen.2020.13136

EMA (2021) https://www.ema.europa.eu/en/news/covid-19-vacci ne-astrazeneca-benefits-still-outweigh-risks-despite-possiblelink-rare-blood-clots. [Accessed 8 April 2021]

Ferrara F (2020) Antirheumatic in SARS-cov-2: benefit or risk? Italian J Med 14(2):114-115. https://doi.org/10.4081/itjm.2020. 1290

Ferrara F, Vitiello A (2021) Efficacy of synthetic glucocorticoids in COVID-19 endothelites. Naunyn Schmiedebergs Arch Pharmacol. https://doi.org/10.1007/s00210-021-02049-7

Ferrara F, Granata G, Pelliccia C (2020a) The added value of pirfenidone to fight inflammation and fibrotic state induced by SARS-cov-2: anti-inflammatory and anti-fibrotic therapy could solve the lung complications of the infection? Eur $\mathrm{J}$ Clin Pharmacol 76(11):1615-1618. https://doi.org/10.1007/ s00228-020-02947-4

Ferrara F, Porta R, D'Aiuto V (2020b) Remdesivir and COVID-19. Ir J Med Sci. https://doi.org/10.1007/s11845-020-02401-5

Giovanetti M, Benedetti F, Campisi G et al (2021) Evolution patterns of SARS-cov-2: snapshot on its genome variants. Biochem Biophys Res Commun 538:88-91. https://doi.org/10.1016/j.bbrc.2020.10. 102

Gorbalenya AE (2020) Severe acute respiratory syndrome-related coronavirus: the species and its viruses-a statement of the Coronavirus Study Group. Microbiology. https://doi.org/10.1101/2020. 02.07 .937862

Guarner J (2020) Three emerging coronaviruses in two decades. Am J Clin Pathol 153:420-421

Harrison AG, Lin T, Wang P (2020) Mechanisms of SARS-cov-2 transmission and pathogenesis. Trends Immunol 41(12):1100-1115. https://doi.org/10.1016/j.it.2020.10.004

Hoang VT, Dao TL, Gautret P (2020) Recurrence of positive SARScov-2 in patients recovered from COVID-19. J Med Virol 92(11):2366-2367. https://doi.org/10.1002/jmv.26056

Holm MR, Poland GA (2021) Critical aspects of packaging, storage, preparation, and administration of mrna and adenovirus-vectored COVID-19 vaccines for optimal efficacy. Vaccine 39(3):457-459. https://doi.org/10.1016/j.vaccine.2020.12.017

Horby P (2020) Effect of dexamethasone in hospitalized patients with COVID-19: preliminary report. Infect Dis (except HIV/ AIDS). https://doi.org/10.1101/2020.06.22.20137273

Huang C (2020) Clinical features of patients infected with 2019 novel coronavirus in Wuhan. China, Lancet 395:497-506

Laczkó D, Hogan MJ, Toulmin SA et al (2020) A single immunization with nucleoside-modified mrna vaccines elicits strong cellular and humoral immune responses against SARS-cov-2 in mice. Immunity 53(4):724-732.e7. https://doi.org/10.1016/j. immuni.2020.07.019

Lederer K, Castaño D, Gómez Atria D et al (2020) SARS-cov-2 mrna vaccines foster potent antigen-specific germinal center responses associated with neutralizing antibody generation. Immunity 53(6):1281-1295.e5. https://doi.org/10.1016/j. immuni.2020.11.009

Li Q, Guan X, Wu P et al (2020) Early transmission dynamics in Wuhan, China, of novel coronavirus-infected pneumonia. N Engl J Med 382(13):1199-1207. https://doi.org/10.1056/nejmo a2001316
Locht C (2020) Vaccines against COVID-19. Anaesth Crit Care Pain Med 39(6):703-705. https://doi.org/10.1016/j.accpm.2020.10.006

Oran DP, Topol EJ (2020) Prevalence of asymptomatic SARS-cov-2 infection: a narrative review. Ann Intern Med 173(5):362-367. https://doi.org/10.7326/M20-3012

Polack FP, Thomas SJ, Kitchin N et al (2020) Safety and efficacy of the BNT162b2 mrna Covid-19 vaccine. N Engl J Med 383(27):26032615. https://doi.org/10.1056/nejmoa2034577

Reyes AZ, Hu KA, Teperman J et al (2020) Anti-inflammatory therapy for COVID-19 infection: the case for colchicine. Ann Rheum Dis. https://doi.org/10.1136/annrheumdis-2020-219174

Sewell HF, Agius RM, Kendrick D et al (2020) Covid-19 vaccines: delivering protective immunity. BMJ 371:m4838. https://doi.org/ 10.1136/bmj.m4838

Shimabukuro TT, Cole M, Su JR (2021) Reports of anaphylaxis after receipt of mrna COVID-19 vaccines in the US-December 14 , 2020-January 18, 2021. JAMA. https://doi.org/10.1001/jama. 2021.1967

Somers EC, Eschenauer GA, Troost JP et al (2020) Tocilizumab for treatment of mechanically ventilated patients with COVID-19. Clin Infect Dis. https://doi.org/10.1093/cid/ciaa954

Tande AJ, Pollock BD, Shah ND et al (2021) Impact of the COVID-19 vaccine on asymptomatic infection among patients undergoing pre-procedural COVID-19 molecular screening. Clin Infect Dis. https://doi.org/10.1093/cid/ciab229

Vitiello A, Ferrara F (2020a) Correlation between renin-angiotensin system and severe acute respiratory syndrome coronavirus 2 infection: what do we know? Eur J Pharmacol 883:173373. https://doi. org/10.1016/j.ejphar.2020.173373

Vitiello A, Ferrara F (2020b) Pharmacological agents to therapeutic treatment of cardiac injury caused by Covid-19. Life Sci 262:118510. https://doi.org/10.1016/j.lfs.2020.118510

Vitiello A, Ferrara F (2020c) Remdesivir versus ritonavir/lopinavir in COVID-19 patients. Ir J Med Sci. https://doi.org/10.1007/ s11845-020-02440-y

Vitiello A, Ferrara F (2021) Therapeutic strategies for SARS-cov-2 acting on ACE-2. Eur J Pharm Sci 156:105579. https://doi.org/ 10.1016/j.ejps.2020.105579

Vitiello A, Ferrara F, Pelliccia C et al (2020a) Cytokine storm and colchicine potential role in fighting SARS-cov-2 pneumonia. Italian J Med 14(2):88-94. https://doi.org/10.4081/itjm.2020.124

Vitiello A, La Porta R, Ferrara F (2020b) Sacubitril, valsartan and SARS-cov-2. BMJ Evid Based Med. https://doi.org/10.1136/ bmjebm-2020-111497

Vitiello A, La Porta R, Ferrara F (2020c) Correlation between the use of statins and COVID-19: what do we know? BMJ Evid-Based Med. https://doi.org/10.1136/bmjebm-2020-111589

Vitiello A, Ferrara F, Porta R (2021a) Remdesivir and COVID-19 infection, therapeutic benefits or unnecessary risks? Ir J Med Sci. https://doi.org/10.1007/s11845-020-02482-2

Vitiello A, La Porta R, D'Aiuto V et al (2021b) The risks of liver injury in COVID-19 patients and pharmacological management to reduce or prevent the damage induced. Egypt Liver J. https:// doi.org/10.1186/s43066-021-00082-y

Vitiello A, La Porta R, Ferrara F (2021c) Scientific hypothesis and rational pharmacological for the use of sacubitril/valsartan in cardiac damage caused by COVID-19. Med Hypotheses 147:110486. https://doi.org/10.1016/j.mehy.2021.110486

Vitiello A, Pelliccia C, Ferrara F (2021d) Drugs acting on the reninangiotensin system and SARS-cov-2. Drug Discov Today S13596446(21):00037-00044. https://doi.org/10.1016/j.drudis.2021.01. 010

Wang C, Horby PW, Hayden FG et al (2020a) A novel coronavirus outbreak of global health concern. Lancet 395(10223):470-473. https://doi.org/10.1016/S0140-6736(20)30185-9 
Wang F, Kream RM, Stefano GB (2020b) An evidence based perspective on mrna-SARS-cov-2 vaccine development. Med Sci Monit 26:e924700. https://doi.org/10.12659/MSM.924700

Wang M, Cao R, Zhang L et al (2020c) Remdesivir and chloroquine effectively inhibit the recently emerged novel coronavirus (2019ncov) in vitro. Cell Res 30(3):269-271. https://doi.org/10.1038/ s41422-020-0282-0

Wijnsma KL, Ter Heine R, Moes DJAR et al (2019) Pharmacology, pharmacokinetics and pharmacodynamics of eculizumab, and possibilities for an individualized approach to eculizumab. Clin Pharmacokinet 58(7):859-874. https://doi.org/10.1007/ s40262-019-00742-8

World health organization (WHO) https://www.who.int/emergencies/ diseases/novelcoronavirus2019/situation-reports [Situation Reports March 2021]
Zhang NN, Li XF, Deng YQ et al (2020) A thermostable mrna vaccine against COVID-19. Cell 182(5):1271-1283.e16. https://doi.org/10. 1016/j.cell.2020.07.024

Zhu N, Zhang D, Wang W et al (2019) A novel coronavirus from patients with pneumonia in China, 2019. N Engl J Med 382(8):727-733. https://doi.org/10.1056/nejmoa2001017

Publisher's Note Springer Nature remains neutral with regard to jurisdictional claims in published maps and institutional affiliations. 